\title{
A preliminary study evaluating trans-fat content of pastries in socioeconomically disadvantaged communities of Istanbul
}

\author{
Pinar AY ${ }^{1}$ D, Lubna QUTRANJI² (D), Okan CETIN ${ }^{2}$ (D), Esmatullah REZAI² ${ }^{\mathbb{D}}$, Rohullah FAYAZI ${ }^{2}$ (D), Tanzer GEZER ${ }^{3}$ (D), \\ Zeynep Begum KALYONCU ${ }^{4}$ (D), Ummuhan PECE SONMEZ ${ }^{3}$ (D), Murat GUNER ${ }^{3}$ (D), Elif DAGLI ${ }^{3}$ (D) \\ ${ }^{1}$ Department of Public Health,School of Medicine, Marmara University, Istanbul, Turkey. \\ ${ }^{2}$ Marmara University School of Medicine, Istanbul, Turkey. \\ ${ }^{3}$ Health Institute Association, Istanbul, Turkey. \\ ${ }^{4}$ Nutrition and Dietetics, School of Health Sciences, Atılım University, Ankara, Turkey.
}

Corresponding Author: Pinar AY

E-mail: npay@marmara.edu.tr

Submitted: 26.10.2020 Accepted: 09.12.2020

\begin{abstract}
Objective: Trans-fatty acids (TFAs) pose several risks to human health. World Health Organization recommends the elimination of trans-fat consumption through limiting their use as less than $2 \mathrm{~g} / 100 \mathrm{~g}$ fat. In line with this recommendation, Turkey recently passed a new regulation securing the content of TFAs as less than $2 \mathrm{~g} / 100 \mathrm{~g}$ fat in industrially produced foods. The objective of this study was to determine the proportion of high TFA ( $>2 \mathrm{~g} / 100 \mathrm{~g}$ fat) in pastries among socioeconomically disadvantaged communities of Istanbul before the regulation was put into force.

Materials and Methods: Eight socioeconomically disadvantaged districts were chosen from Istanbul and from each district three neighborhoods with the lowest land values were identified. Pastry samples were collected from 72 shops. TFA content was analyzed at Scientific and Technological Research Council of Turkey (TUBITAK) Marmara Research Center by the ISO 12966-2:2011 method. $\mathrm{p}<0.05$ was set as the level of statistical significance.

Results: The median (25th-75th percentile) value of TFAs was $0.19 \mathrm{~g} / 100 \mathrm{~g}(0.04 \mathrm{~g} / 100 \mathrm{~g}-0.30 \mathrm{~g} / 100 \mathrm{~g})$. None of the samples exceeded the level of $2 \mathrm{~g} / 100 \mathrm{~g}$. There was no difference in TFA content between the districts ( $\mathrm{p}>0.05)$.

Conclusion: Our findings indicate that Turkey could easily comply with the legislative limit of $2 \%$. Still, the compliance should continuously be evaluated in diverse populations of the country.

Keywords: Trans-fatty acids, Elimination, Pastry
\end{abstract}

\section{INTRODUCTION}

Trans-fatty acids (TFAs) are unsaturated fats containing at least one trans-double bond. TFAs can either occur naturally in animal sources such as meat and milk products or they can be industrially produced by partial hydrogenation of vegetable oils. Industrially produced TFAs are present in a variety of products as margarines, chocolates, bakery products and fried foods. They are used widely in the food supply because they extend the shelf life of products, maintain their structure after re-heating and are cheap [1-3].

Despite their wide use TFAs pose several health risks on human health. Consumption of TFAs leads to a $34 \%$ increase in allcause mortality and a $28 \%$ increase in cardiovascular disease mortality $[3,4]$. There are also some studies indicating the association of TFAs with diabetes mellitus, abdominal obesity, breast and colon cancer, cognitive impairment, Alzheimer's disease, allergy, pre-eclampsia, disorders of nervous system, and impaired vision in infants $[1,5]$. Just by eliminating the use of TFAs 540.000 coronary heart disease deaths can be prevented worldwide every year [6]. Since, industrially produced TFAcontaining products cost less, low income communities are even more likely to consume them. Therefore, in order to address the health inequality problems that might arise from TFA consumption, elimination policies need to be implemented globally $[1,2]$.

World Health Organization (WHO) targets the elimination of industrially produced TFAs from the global food supply by 2023 with an aim to reduce the disease risk and positively influence the overall nutritional quality. This translates to limiting the consumption of TFAs to less than $1 \%$ of the total daily energy which is less than $2.2 \mathrm{~g}$ daily intake for a $2000-\mathrm{kcal}$ diet. The recommended strategy is either to ban the use or to set up a mandatory limit of less than $2 \mathrm{~g}$ of industrially produced TFAs per $100 \mathrm{~g}$ of total fat $[3,7]$.

How to cite this article: Ay P, Qutranji L, Cetin O, et al. A preliminary study evaluating trans-fat content of pastries in socioeconomically disadvantaged communities of Istanbul. Marmara Med J 2021; 34(1):75-78. doi: 10.5472/marumj.866632 
In Turkey, there have been some voluntary initiatives requiring the labeling of the TFA content of food products higher than $2 \%$. However, there have been no comprehensive regulatory actions to limit the TFA content up until recently. On 7th of May 2020 the Ministry of Agriculture and Forestry passed a new regulation which restricts the content of TFAs as less than $2 \mathrm{~g} / 100 \mathrm{~g}$ fat for foods intended for the final consumer, including the products supplied for retail. The new regulation will enter into force as of December 312020 [8].

The objective of this study was to evaluate the TFA content of local pastry products before the regulation was implemented. The main aim was to determine the proportion of high TFA (>2 g/100g fat) pastries (börek*) among socioeconomically disadvantaged communities of Istanbul. We studied pastries because an earlier survey revealed that bakery products had the highest TFA contents [9]. However, to our knowledge among the bakery products, local-made pastries were not evaluated previously.

\section{MATERIALS and METHODS}

The sampling unit was pastry shops located in socioeconomically disadvantaged communities of Istanbul. The sample size was calculated as 72 pastry shops assuming the proportion of high TFA use ( $>2 \mathrm{~g} / 100 \mathrm{~g}$ fat) in pastries as $25 \%$, a confidence level of $95 \%$ and a margin of error of $10 \%$.

The minimum $\mathrm{m}^{2}$ unit land values published annually by the Revenue Administration were used in order to identify the socioeconomically disadvantaged communities of Istanbul [10]. Sampling was carried out in three stages. In the first stage, eight districts with low land values were chosen among the 39 districts in Istanbul. In the second stage, from each chosen district, three neighborhoods with the lowest land values were identified. In the last stage, three public schools (one primary, one secondary and one high school) were chosen from each neighborhood. Researchers visited the schools and identified the pastry shops that were located closest to each school. Pastry samples (without meat) were collected from 72 shops. TFA content was analysed at Scientific and Technological Research Council of Turkey (TUBITAK) Marmara Research Center by the ISO 129662:2011 method. TFA values were defined as grams per $100 \mathrm{~g}$ fat.

This study was approved by the Institutional Clinical Research Ethics Committee of Marmara University, School of Medicine (document no: 09.2019.778).

\section{Statistical Analysis}

Descriptive statistics were presented as medians, 25th-75th percentiles, minimum and maximum values. Continuous variables between multiple groups were analyzed by the Kruskal Wallis test since the data did not follow the normal distribution. A p-value less than 0.05 was set as the level of statistical significance.

* Börek: Savory pastry product from Turkish cuisine

\section{RESULTS}

The median (25th-75th percentile) value of TFAs was $0.19 \mathrm{~g} / 100 \mathrm{~g}$ $(0.04 \mathrm{~g} / 100 \mathrm{~g}-0.30 \mathrm{~g} / 100 \mathrm{~g})$. The minimum and the maximum values were $0.004 \mathrm{~g} / 100 \mathrm{~g}$ and $1.06 \mathrm{~g} / 100 \mathrm{~g}$, respectively. None of the samples exceeded the level of $2 \mathrm{~g} / 100 \mathrm{~g}$. All the samples except two had TFA content less than $1 \mathrm{~g} / 100 \mathrm{~g}$. Figure 1 presents the box plot graph of the TFA levels among the 72 pastries. There was no difference in TFA content between the eight districts ( $>0.05)$. TFA levels by district are presented in Figure 2 .

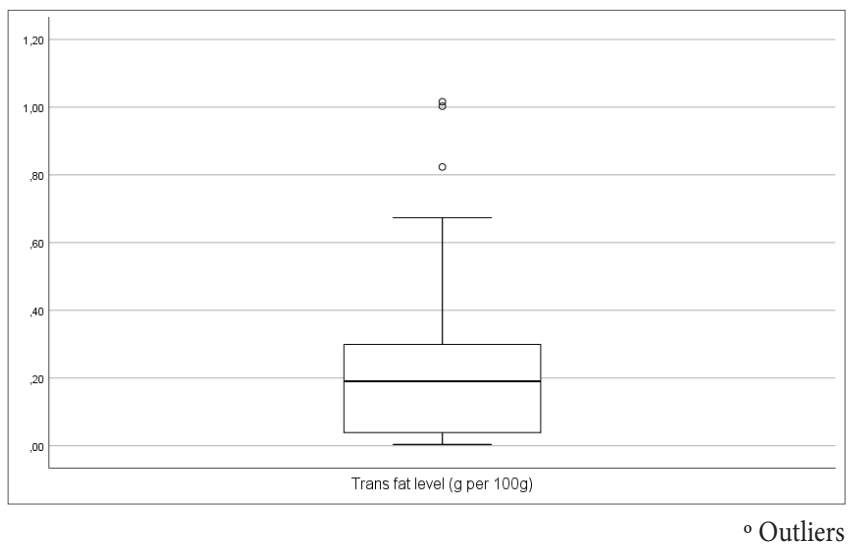

Figure 1. Trans-fat level ( $g$ per $100 g$ ) in pastries

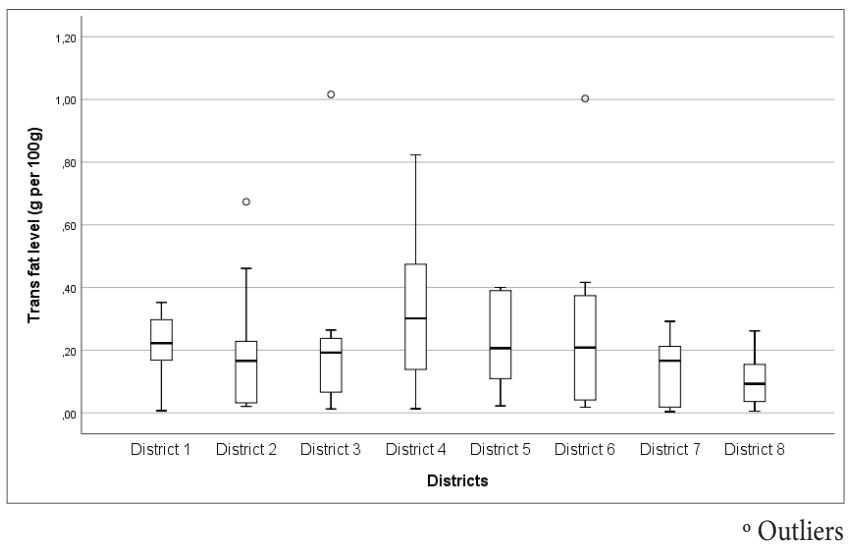

Figure 2. Trans-fat level ( $g$ per $100 g$ ) in pastries by district $(p>0.05)$

\section{DISCUSSION}

The present study evaluated the TFA content of 72 pastry samples obtained from eight low income neighborhoods of Istanbul. Among all industrially produced food, bakery and pastry products were shown to pose a special risk for TFA exposure in different countries [9,11-15]. A study carried out in Canada identified bakery products as the major source of TFAs among healthy pregnant women [11]. A study evaluating pastry 
products in the Polish market indicated that approximately one third of the samples had more than $2 \%$ of TFAs [12].

Another study carried out in Zurich revealed that fine bakery products had the highest TFA values [13]. Home-made food sold by street vendors might also be a source of TFAs. A study evaluating street food in an urban environment in Moldova documented that home-made pastries had a high TFA content. The authors reported that for some of the pastries, one serving had over half the daily WHO upper limit for TFA [14]. Similar findings were also reported from Turkey. Karabulut assessed the frequently consumed foods and determined that bakery products had the highest TFA contents ranging from 0.99 to $17.77 \mathrm{~g} / 100 \mathrm{~g}$ fat [9].

To our knowledge this is the first comprehensive study with a focus of evaluating TFA content of pastries which make up an important portion of bakery products in Istanbul, Turkey. Our findings indicate that the TFA content was less than $2 \mathrm{~g} / 100 \mathrm{~g}$ in all of the pastry samples. All samples, except two had TFA content less than $1 \mathrm{~g} / 100 \mathrm{~g}$. These results support the fact that Turkey could easily comply with the recommendations of the WHO's REview, Promote, Legislate, Assess, Create, Enforce (REPLACE) Initiative. WHO had developed REPLACE Initiative as a roadmap strategy for countries in order to eliminate the TFAs from the global food supply. One of the actions recommended in the REPLACE Initiative is to implement regulatory actions in order to eliminate industrially produced TFAs. Countries can either set a mandatory limit of $2 \mathrm{~g} / 100 \mathrm{~g}$ of total fat or totally ban partially hydrogenated oil through classifying them as unsafe [3]. Research had indicated that among policies aimed at reducing TFAs, bans or setting mandatory limits were identified as the most effective, economical, and equitable policy approach [16]. Denmark used this strategy and limited industrially produced TFAs in foods to a maximum of $2 \%$ in 2004 and had successfully reduced the exposure to a high TFA diet at the individual level [17].

Our study has some limitations. Firstly, the level of TFAs were evaluated for only a special type of pastry (börek). Hence, there might be other bakery products that pose a risk for TFA exposure which were not assessed in this study. Another limitation is related to the setting of the study. We evaluated the pastries marketed in selected neighborhoods in eight districts of Istanbul. The city has quite a heterogeneous market for food commodities which necessitate a broader assessment. We also collected samples from pastry shops only, and neither the products sold by street vendors nor the home-cooked pastries were evaluated. Nevertheless, assessing high number of samples at a period close to the introduction of the new regulation in Turkey provided up-to-date information on the TFA content of a product that is widely consumed by Turkish consumers [18].

Our study revealed that pastries, which might have been an important source of dietary TFAs, had TFA levels less than $2 \%$. This finding shows that Turkey could easily comply with the legislation limit of $2 \%$ TFAs. Granting, compliance to the regulation should continuously be evaluated through monitoring the TFA content of different food products in diverse populations of the country.

\section{Compliance with Ethical Standards}

Ethical Approval: This study was approved by the Institutional Clinical Research Ethics Committee of Marmara University, School of Medicine (document no: 09.2019.778).

Funding: This study was conducted by the Health Institute Association with project funding from the Bloomberg Initiative Grants Program (TURKEY-RIR-04 Public mobilization towards elimination of trans - fats in Turkey) administered by the Campaign for Tobacco Free Kids. The funders had no role in study design, data collection and analysis, decision to publish, or preparation of the manuscript.

Conflict of interest: The authors declare no conflict of interest.

Authors' Contrubition: Concept and Design: P.A., Z.B.K., T.G., U.P.S., M.G., E.D., Supervision: T.G., E.D., Resources: M.G., E.D. Materials: P.A., Z.B.K., T.G., U.P.S., M.G., E.D., Data Collection and Processing: L.Q., O.C., E.R., R.F., Analysis and Interpretation: P.A.,, Z.B.K.,, E.R., R.F., Literature Search: P.A., E.R., R.F., Writing the Article: P.A., L.Q., O.C., Critical Review: P.A., Z.B.K., T.G., E.D. All authors approved the final version of the article.

\section{REFERENCES}

[1] Dhaka V, Gulia N, Ahlawat KS, Khatkar BS. Trans fats-sources, health risks and alternative approach - A review. J Food Sci Technol 2011 ;48:534-41. doi: 10.1007/s13197.010.0225-8.

[2] World Health Organization. Eliminating trans fats in Europe: A policy brief. WHO Regional Office for Europe, 2015.

[3] World Health Organization. REPLACE Transfat: An action package to eliminate industrially-produced trans-fatty acids. World Health Organization 2018.

[4] de Souza RJ, Mente A, Maroleanu A, et al. Intake of saturated and trans unsaturated fatty acids and risk of allcause mortality, cardiovascular disease, and type 2 diabetes: systematic review and meta-analysis of observational studies. BMJ 2015;351:h3978. doi: 10.1136/bmj.h3978.

[5] Ginter E, Simko V. New data on harmful effects of trans-fatty acids. Bratisl Lek Listy 2016;117:251-3.

[6] Wang Q, Afshin A, Yakoob MY, et al. Impact of nonoptimal intakes of saturated, polyunsaturated, and trans fat on global burdens of coronary heart disease. J Am Heart Assoc 2016 ;5pii: e002891. doi: 10.1161/JAHA.115.002891.

[7] Ghebreyesus TA, Frieden TR. REPLACE: a roadmap to make the world trans fat free by 2023. Lancet 2018 ;391(10134):19781980. doi: 10.1016/S0140-6736(18)31083-3.

[8] T.C. Resmi Gazete [Official Gazette], 7th May, 2020 No. 31120.

[9] Karabulut I. Fatty acid composition of frequently consumed foods in Turkey with special emphasis on trans fatty acids. Int J Food Sci Nutr 2007;58:619-28.

[10] Revenue Administration, Plot and Land Square Meter Unit Values: https://www.gib.gov.tr/yardim-ve-kaynaklar/yayinlar/ arsa-ve-arazi-asgari-metrekare-birim-degerleri [Accessed 06 February 2020]. 
[11] Elias SL, Innis SM. Bakery foods are the major dietary source of trans-fatty acids among pregnant women with diets providing 30 percent energy from fat. J Am Diet Assoc 2002;102:46-51.

[12] Żbikowska A, Onacik-Gür S, Kowalska M, Rutkowska J. Trans fatty acids in Polish pastry. J Food Prot 2019;24:1028-33. doi: 10.4315/0362-028X.JFP-18-497. Epub ahead of print. PMID: 31124708.

[13] Richter EK, Shawish KA, Scheeder MRL, Colombani PC. Trans fatty acid content of selected Swiss foods: The TransSwissPilot study. J Food Compost Anal 2009;22:479-84.

[14] Albuquerque G, Gelormini M, de Morais IL, et al. Street food in Eastern Europe: a perspective from an urban environment in Moldova. Br J Nutr 2020; 28;124:1093-101. doi: 10.1017/ S000.711.4520002020.
[15] Żbikowska A, Rutkowska J, Kowalska M. Consumption safety of pastries, confectioneries, and potato products as related to fat content. J Am Coll Nutr 2015;34:507-14. doi: 10.1080/07315.724.2014.942472

[16] Downs SM, Bloem MZ, Zheng M, et al. The impact of policies to reduce trans fat consumption: a systematic review of the evidence. Curr Dev Nutr 2017; 1: cdn.117.000778. doi: $10.3945 / \mathrm{cdn} .117 .000778$

[17] Stender S, Dyerberg J, Bysted A, Leth T, Astrup A. A trans world journey. Atheroscler Suppl 2006;7:47-52.

[18] Karadağ MG, Çelebi F, Ertaş Y, Şanlıer N. Geleneksel Türk mutfağından seçmeler: Besin öğeleri açısından değerlendirilmesi. Ankara: Detay Yayıncılık, 2014 